\title{
The Political Economy of the Euro Crisis
}

\section{Citation}

Copelovitch, Mark, Jeffry Frieden, and Stefanie Walter. 2016. "The Political Economy of the Euro Crisis." Comparative Political Studies 49 (7) (March 14): 811-840. doi:10.1177/0010414016633227.

\section{Published Version}

10.1177/0010414016633227

\section{Permanent link}

http://nrs.harvard.edu/urn-3:HUL.InstRepos:33694190

\section{Terms of Use}

This article was downloaded from Harvard University's DASH repository, and is made available under the terms and conditions applicable to Open Access Policy Articles, as set forth at http:// nrs.harvard.edu/urn-3:HUL.InstRepos:dash.current.terms-of-use\#OAP

\section{Share Your Story}

The Harvard community has made this article openly available.

Please share how this access benefits you. Submit a story.

Accessibility 


\title{
The Political Economy of the Euro Crisis
}

\author{
Mark Copelovitch \\ University of Wisconsin - Madison \\ copelovitch@wisc.edu \\ Jeffry Frieden \\ Harvard University \\ jfrieden@harvard.edu \\ Stefanie Walter \\ University of Zurich \\ walter@ipz.uzh.ch
}

Lead article for the special issue "The Political Economy of the Euro Crisis," forthcoming in Comparative Political Studies 
The euro crisis has developed into the most serious economic and political crisis in the history of the European Union (EU). By 2016, nine years after the outbreak of the global financial crisis in 2007, economic activity in the EU and the Eurozone was still below its precrisis level. At this point, the joint effects of the global financial crisis and the euro crisis have caused more lasting economic damage in Europe than the Great Depression of the 1930s (Crafts, 2013). The political consequences have also been severe. Conflict among EU member states has threatened the progress of European integration, while polarization and unrest have unsettled domestic politics in a host of European countries. The crisis has indeed brought into question the very nature and future of European integration generally, and of monetary integration specifically.

To date, there has been substantial economic analysis of the crisis in the Eurozone, which has recently culminated in the emergence of a widely shared consensus on its causes (Baldwin et al., 2015). However, economists often fail to appreciate the large role that politics has played in the run-up, evolution, and attempts at resolution of the euro crisis. The typical economic approach has been to note that the Eurozone is not an optimal currency area ${ }^{1}$, and to subsequently conclude that the long-term survival of the Eurozone requires the creation of a set of institutions to act as substitutes - such as fiscal union, banking union, and/or the establishment of a larger, permanent transfer mechanism to replace the European Stability Mechanism (e.g., De Grauwe, 2013; Lane, 2012; Pisani-Ferry, 2012). This economic approach is a useful starting point, as it highlights the structural problems underlying the euro crisis and hindering its resolution: a lack of labor mobility, asymmetric vulnerability to shocks, and the absence of

\footnotetext{
${ }^{1}$ Based on the criteria set forth in the canonical studies by Mundell (1961), McKinnon (1963), and Kenen (1969).
} 
sufficient fiscal stabilizers. Nevertheless, this approach is not grounded in a realistic appraisal of what policies aimed at resolving the crisis are politically feasible, and it has led most economists to focus on the optimal design of a fiscal or banking union necessary to ensure the survival of the Eurozone, rather than on developing proposals articulating how the Eurozone can become more viable under existing political constraints.

Not surprisingly, political scientists' analyses of the euro crisis have focused more closely on examining and understanding the domestic and international politics of the crisis. These analyses have provided valuable insights into the effects of the crisis on important issues such as European integration (e.g., the special issues edited by Ioannou et al., 2015; Menz \& Smith, 2013; Tosun et al., 2014), voting behavior and public opinion (e.g., the special issues edited by Bellucci et al., 2012; Usherwood \& Startin, 2013), the welfare state (e.g., the special issue edited by Heins \& de la Porte, 2015), and democratic politics more generally (e.g., Cramme \& Hobolt, 2014). Yet just as economists often do not pay enough attention to politics, most political scientists have tended to discount the economic constraints, trade-offs, and dynamics underlying the euro crisis and the policy options available to policymakers. ${ }^{2}$ Although all of these studies recognize the enormity of the crisis, they frequently treat the crisis either as a normal recession or as a European crisis sui generis. Those studies which treat the euro crisis as a normal recession (or simply as a continuation of the broader global financial crisis of 2007-9), ${ }^{3}$ fail to fully appreciate the tensions created within a currency union comprising a divergent set of countries. Indeed, the euro crisis is neither simply a shock resulting from global factors (e.g., the collapse of Lehman Brothers), nor a regular, though prolonged, recession. Rather, it is the result

\footnotetext{
${ }^{2}$ Some notable exceptions include Hall (2012), Scharpf (2013), Johnston et al. (2014), or Bechtel et al. (2014).

${ }^{3}$ While these episodes are linked chronologically - and while the Great Recession has certainly exacerbated the severity of the euro crisis (Mody \& Sandri, 2012) - the underlying economic and political causes of the euro crisis are separate from those of Great Recession.
} 
of more than a decade of tensions accumulating within EMU since its foundation in 1999. On the other hand, those studies within the European politics literature emphasizing the uniqueness of the euro crisis recognize this special setting, but largely underestimate the extent to which the euro crisis resembles past balance-of-payments and debt crises. ${ }^{4}$ As such, they fail to draw upon the rich set of theoretical approaches to understanding financial crises, as well as a wealth of empirical investigations of these past crises that can enhance our understanding of the dynamics and politics in the euro crisis.

In short, economists analyzing the euro crisis have largely assumed politics away as a second-order problem, while political scientists often either under- or over-emphasize the specific constraints of crisis management in a monetary union. This has led to a situation where we have only begun to understand how the politics and economics of the crisis are intertwined. This is puzzling because recent work on the political economy of international money and finance has generated rich insights about the politics of exchange rates, monetary unions, and financial crises that can enrich our understanding of political economy of the euro crisis.

In this special issue, we focus specifically on analyzing the politics of the Euro crisis using the tools of political economy and applying the insights generated by past research on the politics of international money and finance to provide a richer understanding of the political and economic constraints created by the crisis and encountered by Eurozone governments as they attempt to resolve it. The aim of the special issue is to improve our understanding of the causes, consequences, and implications of the highly unusual nature of the euro crisis: a financial crisis among developed countries within a supranational monetary union.

\footnotetext{
${ }^{4}$ For an overview of the commonalities of these past crises, see Reinhart and Rogoff (2010) and Chinn and Frieden (Chinn \& Frieden, 2011).
} 
The remainder of this introductory essay proceeds as follows. First, we begin with a summary of the course of the crisis and of its underlying causes, in order to set the stage for the analyses that follow. We then review the ways in which comparative and international political economy can help us understand the crisis, and we summarize the articles in the rest of the special issue. Finally, we conclude with some thoughts about future research paths on the political economy of the Euro crisis, as well as a brief discussion of how the special issue informs our understanding of the long-term prospects for the Eurozone and European integration.

\section{The crisis: a brief chronology}

In January 2009, European policymakers celebrated the tenth anniversary of the euro's introduction. Europe's Economic and Monetary Union (EMU) had become a reality in January 1999, when a group of eleven EU member states adopted the euro for financial transactions and later replaced their national currencies with the new common currency. Although there had been considerable skepticism about the viability of this project in the years preceding the euro's introduction (for reviews of this literature, see, for example, Enderlein \& Verdun, 2009; Jonung \& Drea, 2010), the general perception among policymakers at the end of the euro's first decade was that it had been an "unquestionable success" and a "rock of macroeconomic stability," that had helped Europe to weather the 2007-08 global financial crisis. ${ }^{5}$

Unfortunately, this optimism proved premature. In late 2009, the newly elected Greek government disclosed that the country's budget deficit was significantly higher than previously estimated and far higher than the Eurozone rules established in the Stability and Growth Pact allowed. When the major rating agencies subsequently downgraded Greece's credit ratings in

\footnotetext{
${ }^{5}$ Speeches by Jean-Claude Juncker, President of the Eurogroup, and Hans-Gerd Pöttering, President of the European Parliament, at the celebration for the euro’s 10th anniversary, Strasbourg, 13 January 2009.
} 
December 2009, and spreads on Greek bonds soared to pre-EMU levels, the euro crisis had begun. Despite implementing austerity measures in the first months of 2010, the Greek government soon had to ask for outside help. Such help, however, did not materialize quickly, as European leaders engaged in long and intense debates about whether and how to support the country. In early May 2010, they finally approved a financial assistance program, in which Eurozone member states together with the IMF would provide Greece with financial assistance in return for fiscal austerity and structural reforms. The implementation of these measures proved politically difficult, however, as Greek policymakers faced widespread domestic protests against the policies in question.

In addition to the Greek assistance package, European policymakers tried to combat the crisis with additional policy measures. They created the European Financial Stability Facility (EFSF), with a mandate to provide assistance to euro area Member States in financial distress and a lending capacity of $€ 440$ billion. ${ }^{6}$ Negotiations also began to strengthen the Stability and Growth Pact and to introduce greater macroeconomic surveillance, including attention to the emergence of macroeconomic imbalances - a process that would eventually lead to the adoption of the "Six-Pack" of reforms in December 2011. The ECB announced exceptional measures that included sovereign debt purchases on secondary markets. ${ }^{7}$ In December 2010, the European Council agreed to establish a permanent crisis resolution mechanism for the countries of the euro area, the European Stability Mechanism (ESM), which began operating in September 2012, and replaced temporary EU funding programs such as the EFSF.

In spite of these efforts, the crisis deepened in the following months. Borrowing costs soared in the Eurozone periphery, especially for Ireland and Portugal - where huge credit booms

\footnotetext{
${ }^{6}$ On the politics of the EFSF's creation, see Gocaj and Meunier (2013).

${ }^{7}$ Under the so-called Securities Market Program (SMP), the ECB would buy up Greek, Irish, Italian, Portuguese, and Spanish bonds over the next months.
} 
had turned into busts during the global financial crisis - against the backdrop of worsening outlooks in several Eurozone countries and speculation that private creditors might have to share the cost of future defaults with taxpayers. Both countries received EU-IMF bailouts - €85 billion for Ireland in November 2010, and €78 billion for Portugal in May 2011 - under the auspices of the Troika, a tripartite committee formed by the European Commission, European Central Bank (ECB), and International Monetary Fund (IMF). With bond spreads on Spanish and Italian government bonds the next to rise, the ECB announced that it would resume its sovereign bond purchases to lower crisis countries’ borrowing costs.

In the meantime, tensions mounted in Greece about new austerity measures, and for the first time the possibility of a "Grexit" - a Greek exit from the Eurozone - was openly discussed. After difficult and protracted negotiations, Greece finally received a second financial assistance package totaling €130 billion in March 2012, which for the first time included a significant haircut for private creditors. In June 2012, Spain requested and received financial assistance of up to $€ 100$ billion to recapitalize its banking sector. In the same month, Cyprus requested a financial assistance package, which it received after long negotiations in March 2013 and in the context of which heavy losses were forced on wealthy bank depositors. With Europe in recession, pervasive downgrading of European countries’ credit ratings, widespread anti-austerity protests, and the more general sense that policymakers were doing too little, too late to address the underlying problems, the Eurozone crisis continued to accelerate.

The Euro crisis also generated large political costs for member-state governments. Domestically, the implementation of austerity measures and structural reforms proved difficult and politically costly. One government after the other fell, radical populist parties were strengthened, and general satisfaction among citizens with the European Union reached 
unprecedented lows (Eurobarometer, 2012). At the European level, policymakers struggled to reform the architecture of EMU. Issues such as banking and fiscal union and other measures were hotly debated and highly controversial. Not surprisingly, the outcomes of the political bargains were compromises. In March 2012, all European leaders, except those from the UK and the Czech Republic, signed the "fiscal compact", a treaty designed to force member state governments to balance their budgets over the business cycle. In June 2012, Eurozone leaders endorsed the idea of a banking union, in which Eurozone banks would operate under a set of common rules, with a single supervisory authority and a single resolution mechanism for bank failures. They also proposed a "growth compact," following increasing calls for an agenda focused on growth, rather than austerity. Marking a turning point of the crisis, the ECB also stepped up its interventions, with Mario Draghi famously stating in July 2012, that the ECB stood ready to do "whatever it takes to preserve the euro" und unveiling a new bond purchasing program, called “Outright Monetary Transactions” (OMT).

After these events, a semblance of calm and stability returned to the Eurozone. Severe market stress subsided, adjustment in the crisis countries progressed, and the first countries began to exit the Eurozone assistance programs (Ireland in December 2013, Spain in January 2014, Portugal in May 2014). But despite these encouraging developments, the crisis took center stage again in January 2015, when Alexis Tsipras and the left-wing Syriza party were voted into office in Greece, on the promise to simultaneously end austerity and keep the country in the euro-zone. In the ensuing months, protracted and difficult negotiations between Greece and the Troika ultimately ended in deadlock. With the expiration deadline for Greece’s existing program approaching, liquidity problems mounting, and a take-it-or-leave-it offer from the creditors on the table, Tsipras broke off the negotiations and called a referendum on the proposal - 
recommending that voters reject the proposal in order to improve Greece's bargaining position. What followed was an intense week, during which Greece had to close its banks and to impose capital controls and became the first industrialized country to default on an IMF loan. Although European and Greek policymakers warned that a rejection of the creditor proposal would lead to "Grexit," and polls showed that a large majority of Greeks wanted to remain in the Eurozone (Dinas et al., 2015), 61\% of voters rejected the creditor proposal in the referendum. This vote tested the eurozone's pledge to be an irrevocable and irreversible monetary union in unprecedented ways. Several European governments openly called for Greece’s permanent or temporary exit from the monetary union. After a Euro-summit that lasted more than 17 hours, Greece ultimately accepted a third bailout package whose terms were harsher than those rejected by the Greek people in the referendum.

Meanwhile, developments in the other crisis countries were somewhat more encouraging. Growth picked up and turned positive in Ireland, Portugal and Spain in 2014, and the ongoing crisis in Greece hardly affected the bond spreads in these countries. Overall, the European economy entered a phase of recovery, boosted also by the ECB's decision to adopt and implement quantitative easing (QE) in January 2015 to combat deflationary pressures. Nevertheless, huge challenges remain for the crisis countries and the Eurozone as a whole. At the time of writing, growth remains sluggish throughout most of the region, unemployment rates have reached record highs, especially among the young, and public debt remains substantial. The crisis has exposed the difficulties of crisis management in a confederation of states bound together by economic, but not political union. And the rise of anti-European parties in the European elections of June 2014, the political stalemates that have followed the 2015 elections in both Portugal and Spain (which brought large wins for political parties opposed to austerity 
and/or the political establishment), and mounting social and political tensions attest to the serious and enduring domestic political consequences of the Euro crisis.

Ultimately, the underlying causes of the crisis have not been resolved, and the narrative that the crisis has ended is misguided. Thus, while the short-term panic has subsided once again, serious questions remain about both the management and resolution of the ongoing crisis and the future of the monetary union itself.

\section{Analyzing the causes and dynamics of the euro crisis}

A good political economy analysis of the euro crisis requires a clear understanding of why the crisis occurred in the first place. Fortunately, there is a growing consensus among economists about the causes of the euro crisis: The crisis was a classic balance-of-payments crisis, triggered by a "sudden stop" (Calvo, 1998) of capital inflows into those Eurozone countries with large current account deficits, which had become dependent on foreign lending. The crisis was amplified by the lack of a lender of last resort, the fact that the classic crisis response - devaluation - was no longer among the menu of options, the close links between banks and governments as well as the predominance of bank financing in the Eurozone, and rigid factor and product markets (Baldwin et al., 2015). As such, the euro crisis has its roots in features of the construction of the Economic and Monetary Union (EMU) itself - features which in turn are due to the difficult political economy of the creation of the single currency (for an overview, see Eichengreen \& Frieden, 2001). At the time of the introduction of the euro, there were at least four important issues that had not yet been resolved. Ultimately, all four contributed to the crisis as it unfolded. 


\section{a) Macroeconomic divergence.}

It is challenging to adopt a single monetary policy for a highly differentiated set of member countries that do not quality as an optimum currency area (McKinnon, 1963; Mundell, 1961). Therefore, the first problem that EMU, like any currency union, faced was the underlying differences in macroeconomic conditions among the member states. In 1999, at the outset of EMU, there were, in fact, substantial macroeconomic divergences among the member-states. ${ }^{8}$ Most importantly, there was a clear difference between the Northern European countries and the peripheral European economies. Northern European countries were growing slowly or not at all, whereas the peripheral European countries - not just in the South, but also including Ireland and, outside the Eurozone, some countries in Central and Eastern Europe - were instead growing rapidly, with wages and prices rising. ${ }^{9}$

Germany and Spain are important and representative examples. In the simplest terms, the German economy was stagnant in the years following the euro's introduction, while Spain's was growing quite rapidly. But a decade of wage restraint and austerity following German unification made the country's manufacturing sector increasingly competitive, as Germany returned to its traditional export-oriented position. In Spain, on the other hand, wages were rising quickly as the economy boomed. Consequently, inflation was at or near zero in Germany, while prices were rising more rapidly in Spain. Between 1998 and 2007, German inflation averaged just 1.5\% a year, while in Spain it averaged 3.2\%. Compounded over nearly a decade, these differentials in growth and inflation led to a substantial divergence in labor costs within the Eurozone: between

\footnotetext{
${ }^{8}$ This led many observers to doubt the feasibility of a currency union in the European context, which clearly did not constitute an "optimum currency area“ (e.g., Bayoumi \& Eichengreen, 1992; P. A. Hall \& Franzese, 1998).

${ }^{9}$ In what follows, we use "peripheral” and "Southern" interchangeably, despite the geographical inaccuracy.
} 
1998 and 2007, unit labor costs in Germany actually fell by 3.9\% while in Spain they rose by $30.4 \% .^{10}$

Despite these divergences, the ECB could only implement a single monetary policy for the Eurozone, and it chose one that attempted to find a middle ground between the needs of Northern and Southern Eurozone member-states. For most of this period, the ECB's main interest rate was around 3\%. This meant, most importantly, that interest rates in the peripheral countries were very low compared to national inflation: real interest rates in Germany were about 2\%, while they were slightly negative in Spain. These low, even negative, real interest rates, gave households and other economic agents in peripheral countries such as Spain strong incentives to borrow, while stagnation in the North gave investors strong incentives to lend. In Germany, moreover, the traditionally high savings rate rose further as its population aged and trade surpluses accumulated. The result was a massive flow of funds from the surplus countries of Northern Europe to the deficit countries of the Eurozone periphery.

These capital flows from North to South reinforced the macroeconomic divergences within the monetary union. In the periphery, the debt-financed consumption boom raised wages and prices, which further increased the difference between the two regions. Trends in the various countries' real effective exchange rates indicated the growing divergence: between 1999 and 2008, Germany’s intra-Eurozone real exchange rate declined by nearly 20 percent, while the Spanish real exchange rate appreciated by more than 25 percent. $^{11}$ In sum, the ECB's single monetary policy led to a very unbalanced pattern of capital flows and growth in the Eurozone's first decade.

\footnotetext{
${ }^{10}$ Data from Eurostat, http://epp.eurostat.ec.europa.eu/tgm/table.do?tab=table\&init=1\&plugin=0\&language=en\&pcode=tsdec33 $\underline{0}$ accessed March 6, 2013.

${ }^{\overline{11}}$ European Commission/OECD, cited in Carlin and Soskice (2014).
} 
These imbalances were reflected almost immediately in the balance of payments of the Northern and peripheral European countries. In 1998, both Spain and Germany had small current account deficits of about one percent of GDP, while Italy and Ireland were running surpluses. By 2008, however, Germany’s current account surplus had surged to 6 percent of GDP, while Spain, Ireland, and Italy had deficits of 10, 6, and 3 percent respectively (World Bank, 2014). Simply put, Northern European surpluses - above all, those of Germany - were financing the Eurozone periphery's deficits. Contrary to popular impressions, the vast majority of these loans went to private borrowers. Greece and, to a lesser extent, Portugal, were the only peripheral countries whose governments ran major budget deficits in this period. Capital inflows to Spain, for example, went almost entirely to the private financial sector and were channeled primarily into the country's booming housing market.

These North-South capital flows accelerated the divergences among Eurozone economies, further speeding growth and price increases in the periphery, especially in such non-tradable sectors as housing. As housing prices rose, incentives to borrow (and lend) rose further, and Northern current account surpluses and Southern deficits grew apace. Political leaders in the North had little reason to discourage their investors from taking advantage of profit opportunities in the periphery, while political leaders in the periphery had little reason to discourage their people from participating in the debt-financed expansion. Eventually, this boom turned into a huge problem once the bubble burst. Not surprisingly, the larger a country's current account deficit, the more severely the country got hit by the euro crisis (Johnston et al., 2014; Wihlborg et al., 2010). 


\section{b) Lack of fiscal policy coordination.}

The regional imbalances that resulted from these macroeconomic divergences, and which were exaggerated by the large-scale capital flows, might have been reduced if national governments had collaborated to counteract some of these trends with their fiscal policies. By imposing more restrictive fiscal policies, booming peripheral countries such as Spain could have restrained demand, which would have limited the size of the current account deficit and the inflow of foreign capital. Likewise, surplus countries such as Germany could have adopted more expansionary fiscal policies to stimulate domestic demand and restrain capital outflows to the South.

Several reasons explain why European policymakers did not coordinate their fiscal policies to address the growing imbalances across the Eurozone. First, countries give up their monetary policy autonomy when joining a monetary union. At the same time, the effectiveness of fiscal policy is enhanced (Mundell, 1963). As a result, national political leaders were loath to give up their one remaining tool of national macroeconomic policy, especially one that had just become more effective. Second, taking away the (fiscal) punch bowl when the party is rolling has always been difficult for policymakers, and this was true for policymakers in the peripheral countries as well. The fact that markets priced government borrowing at much lower interest rates than before the start of EMU further created incentives to borrow on financial markets (Bernoth et al., 2012). The closest comparisons to this situation might be to debt crises of subnational units (states, provinces) in such federal unions as the United States or Argentina, but in these last instances the powers of the sub-national units are far weaker than those of the member states of the EU, while the powers of the federal governments were far stronger than those of the 
EU Commission. While all members of the Eurozone share a common central bank, they have complete autonomy on fiscal policy as well as on most other economic and regulatory policies.

The architects of EMU recognized these problems and constructed the Stability and Growth Pact (SGP) to ensure fiscal discipline across the Eurozone. However, these provisions proved inadequate, providing a third reason why fiscal policies were not coordinated. These rules were never truly enforced, especially once the two largest member states, France and Germany, violated them with impunity in the first five years of the monetary union and as influential states tweaked them in their favor (see the paper by Hallerberg and Baerg in this special issue). In addition, in many peripheral countries the fiscal risks associated with the large capital inflows did not show up in their public debt and deficit figures. Because these capital inflows largely poured into the private sector, which boomed and generated fiscal revenues, the countries' fiscal policies did not appear overly pro-cyclical in the years preceding the crisis. For example, both Ireland and Spain, two of the countries most strongly hit by the crisis, recorded fiscal surpluses in the years preceding the crisis. ${ }^{12}$ The Eurozone problems only turned into a sovereign debt crisis after the Irish and Spanish governments had to support domestic banks badly hurt by the global financial crisis, turning private debt into public debt.

\section{c) Fragmented financial regulation.}

While the Eurozone quickly became a largely integrated single financial market, financial regulation remained very decentralized in the hands of national central banks and regulatory agencies. This created the possibility for regulatory arbitrage, as financial institutions exploited

\footnotetext{
${ }^{12}$ Eurostat, General government deficit (-) and surplus (+) - annual data http://epp.eurostat.ec.europa.eu/tgm/table.do?tab=table\&plugin=1\&language=en\&pcode=teina200 . Data retrieved September 19, 2014. In fact, there is almost no relationship between a country's pre-crisis public debt level or household deficit and the severity of the crisis (Johnston et al., 2014).
} 
gaps in the regulatory environment to seek out higher-yield, and higher-risk, loans. The fragmented regulatory environment also created great uncertainty as to who would ultimately be responsible for banking problems that might arise within the Eurozone. It also meant that national regulators did not internalize the potential systemic effects of the financial flows taking place.

Nonetheless, national policymakers, regulators, and financial institution resisted attempts to further harmonize or centralize financial regulation, fearing that this would put their own domestic firms at a competitive disadvantage. As a result, financial institutions took on risks that were probably greater than national regulators realized, and certainly created systemic risks that nobody was monitoring. Once the global financial crisis put banking sectors under stress, these risks became readily apparent. The global crisis also exposed the high level of interconnectedness of European financial markets, which created substantial contagion risks and turned even small economies such as Greece into systemically important actors. Thus, the Eurozone crisis hit an economic unit that had an established, respected central bank to make monetary policy but no analogous fiscal or regulatory policymaking body - and hence, no other unitary economic policy instruments.

\section{d) Lack of a credible no-bailout commitment.}

A fourth problem was that many market participants anticipated that if and when financial difficulties arose in one of the Eurozone member states, the other member states would be forced to bail it out. This expectation was widespread, despite attempts by Eurozone and national authorities to insist that there would be no such bailouts. International and regional experience told market operators otherwise: because a major financial meltdown in one country 
could threaten the stability of the entire Eurozone, it would force other countries to respond. ${ }^{13}$ Inasmuch as there were expectations of a bailout, market participants did not have to worry unduly about the risks associated with weaknesses in an individual Eurozone country's financial system (Bernoth \& Erdogan, 2012). Consequently, spreads on borrowing by households and governments in all Eurozone countries declined precipitously when the euro was introduced, and remained extremely small until the crisis (Chang \& Leblond, 2014; Ghosh et al., 2013). For almost ten years, governments and private borrowers in the Eurozone could borrow at interest rates roughly equal to those charged to borrowers in Germany.

For Southern Eurozone countries, the costs of international borrowing consequently fell to historically low levels, which further encouraged borrowing by these economies. This was true both in the case of loans to private industry - such as those made to Spanish and Irish banks and the real estate sector - and in the case of public-sector loans - such as those to the Greek government. If markets had fully accounted for the riskiness of the loans being made, the size of international capital flows would have been smaller and the imbalances among Eurozone countries would have been reduced. However, the markets believed - more or less correctly, as it turned out - that the integrated nature of the single market and single currency made it inevitable that, if a member of the Eurozone fell into crisis, other members would be forced to bail it out. While policymakers protested to the contrary, they could not agree on plausible preparations for such a crisis, and so their commitments were not credible. As a result, public and private borrowers in the periphery accumulated significant foreign debt, and banks and other creditors in the surplus countries accumulated significant exposure to widespread default in the periphery.

${ }^{13}$ For a more general discussion see Gray (2013). 
Ultimately, these four problems came together to bring the Eurozone close to collapse. The massive capital flows from the North to the periphery led to a boom, and then a bubble, in the periphery. As the 2007-2008 crisis accelerated, this bubble burst. Financial institutions throughout the Eurozone turned out to be holding trillions of euros worth of questionable assets. This was true of investors in the creditor (Northern) countries, and of financial institutions in the debtor (peripheral) countries, as much of the lending was intermediated through local banks. Peripheral governments found themselves compelled to bail out their illiquid or insolvent banks, at extraordinary expense. The result was a Eurozone debt crisis, in which peripheral countries owed debts they could not service to Northern European creditors.

Once the crisis hit, it immediately dissolved - as do all balance of payments crises - into bitter conflicts over how the burden of adjusting to the accumulated debts and current account imbalances would be distributed (Frieden, 2015 ; see also the articles by Fernandez and Kuo and by Walter in this special issue). The pure economics of such circumstances is clear: the "asymmetry of the adjustment burden" means that in crisis deficit countries have no choice but to adjust, while surplus countries are under no such pressure. Surplus countries therefore often succeed in shifting a disproportionate part of the adjustment burden onto deficit states. However, the response to the crisis was highly politicized. Surplus countries, home to most of the creditors, insisted that deficit countries impose severe austerity measures to service the debts as contracted, or as close to the original contract as possible. Deficit countries insisted instead on less stringent austerity policies and more extensive relief and debt restructuring.

Debt and balance-of-payments crises not only give rise to political conflict over the distribution of the adjustment burden among countries, but also within countries. Within debtor nations, citizens clashed over who would be asked to sacrifice in order to maintain or restore debt service 
and to rebalance the current account: taxpayers, financial institutions, public employees, beneficiaries of public programs, or others. There are many ways to allocate the costs of servicing accumulated debts and implementing structural reforms, and politics in deficit and debtor nations revolved around determining who would shoulder these costs. Likewise, surplus and creditor nations faced debates about whether and how the country should shoulder some of the adjustment burden, and whether and how it should support struggling financial institutions exposed to default risk in the periphery. As a result, more or less open distributive conflicts have characterized and powerfully affected government policies toward the euro crisis.

These conflicts have been exacerbated by the inability of individual Eurozone governments to control their exchange rate. If, as had happened in the EMS crisis in 1992-3, peripheral governments had been able to devalue, recovery from the crisis would almost certainly have been more rapid - to the benefit of both debtors and creditors. In the absence of this option, however, the crisis has persisted and deepened. All of the Eurozone debtor nations have undertaken serious austerity measures whose costs have fallen primarily on public employees, beneficiaries of public spending, and workers in the private sector. Many countries, especially those under the auspices of the Troika, have implemented far-reaching structural reforms as well, although structural reforms have progressed much more slowly in other countries, such as Italy or France. Taxpayers in the creditor nations in the Eurozone have shouldered financial rescue packages of hitherto unimaginable proportions, whereas investors and the financial sector have benefited from low interest rates and the indirect public support for their investments in the Eurozone periphery.

In light of these large distributive consequences of the crisis, it is perhaps even more striking that the political consequences of these developments have so far been comparatively 
small. While there have been some protests, none of the debtor nations, with the possible exception of Greece, have experienced the kinds of political upheavals we have seen in previous debt and balance of payments crises (see the paper by Genovese, Schneider, and Wassmann in this special issue). And while many governments have fallen and although Eurosceptic parties have recently gained in the polls, the basic institutional set-up, including European Monetary Union, remains essentially unchallenged.

\section{The political economy of the Euro crisis}

As this discussion of the chronology and causes of the Euro crisis implies, political factors have been central to every aspect of the crisis. To a great extent, this is obvious, since EMU has always been, at root, a political project. And yet, the political economy of the euro crisis has not yet been systematically analyzed. Indeed, a frequent refrain at recent academic conferences and among our respective colleagues is that political scientists - and scholars of comparative and international political economy in particular - have had precious little to say about the global and European financial crises of the last decade. Why, it is often asked, have so few articles been published in the top political science journals about these crises? This lament has prompted even broader and stronger critiques of “American IPE” by some scholars, who have derided the subfield as "boring” and accused it of having nothing to say about big questions in the contemporary global economy (Cohen, 2008).

On the one hand, this is a reasonable critique. Scholars of international and comparative political have, indeed, been slow to respond to the Euro crisis with new research. On the other hand, we see this call for new studies and novel theories as premature. Our response to these questions and criticisms mirrors those of some economists, who have responded to handwringing 
within their own discipline (stemming from Queen Elizabeth's famous 2008 question about the global crisis, "Why did nobody notice it?”) by emphasizing that the problem is not a lack of new studies and literature, but rather a failure to understand and apply existing frameworks and bodies of work. $^{14}$

In our view, this is precisely what has been missing from the existing political science literature on the Euro crisis. Existing work in the European and comparative politics literatures tends to overlook the vast amount of scholarship on the politics of exchange rates, capital flows, international monetary and financial institutions, and financial crises over the last three decades. ${ }^{15}$ This work not only includes a well-developed set of theories about central aspects of the euro crises, but also includes important empirical studies of the debt and currency crises of the 1930s, and of similar crises in developing countries since the 1970s. It also includes an earlier, rich literature on the politics of the euro's creation, which has illustrated that the policies necessary for a smooth functioning of EMU are highly unlikely to be adopted, given the domestic political constraints confronting Eurozone governments and the barriers to cooperation among member-states at the European level (see, for example, Dyson \& Featherstone, 1999; Eichengreen \& Frieden, 2001; McNamara, 1998; Sandholtz, 1993).

In recent years, scholars of CPE and IPE have developed a keen understanding of the significant trade-offs confronting policymakers in the realms of fiscal, monetary, financial, and

\footnotetext{
${ }^{14}$ http://www.telegraph.co.uk/news/uknews/theroyalfamily/3386353/The-Queen-asks-why-no-one-sawthe-credit-crunch-coming.html

${ }^{15}$ For exchange rates and monetary policy, see for example (Bearce, 2003; the special issue edited by Bernhard et al., 2002; Bodea, 2010; Copelovitch \& Singer, 2008; Frieden, 1991b; Leblang, 1999; Steinberg, 2015; Walter, 2008). On the political economy of international capital flows, see for example (Gray, 2013; Haggard \& Maxfield, 1996; Mosley, 2003; Quinn \& Toyoda, 2007; Simmons \& Elkins, 2004; Singer, 2004). For international monetary and financial institutions see for example (Chwieroth, 2009; Copelovitch, 2010a, 2010b; Dreher et al., 2009; Rickard \& Caraway, 2014; Vreeland, 2003). For financial crises, see among others (Eichengreen, 1992; Frieden, 1991a; Pepinsky, 2009; Satyanath, 2006; Simmons, 1994; Walter, 2013)
} 
exchange-rate policy, and the implications these trade-offs have for economic policymaking. Policymakers in the Eurozone confront a number of these trade-offs, which strongly affect the incentives they face as they weigh their options. For one, many policy options are constrained by the well-known open-economy trilemma, which follows from the Mundell-Fleming model: When capital markets are open, as is the case in the European Union, policymakers must choose between exchange-rate stability and domestic policy autonomy. IPE research has shown that the costs of sacrificing domestic economic goals in order to achieve exchange rate stability are particularly high for democratically elected policymakers (e.g. Bearce \& Hallerberg, 2011; Broz, 2002; M. Hall, 2008; Sattler \& Walter, 2010; Simmons, 1994), but that these costs also vary substantially across different political settings. For example, veto player configurations (Hallerberg, 2002; Keefer \& Stasavage, 2002), legislative and electoral institutions (Bernhard \& Leblang, 1999) and the influence of special interests (Frieden, 2002; Steinberg, 2015; Walter, 2008) all affect the degree to which foregoing monetary policy autonomy is costly to political leaders. Another implication of the Mundell-Fleming model is that, while monetary policy autonomy is sacrificed in a fixed exchange rate regime like the Eurozone, fiscal policy becomes more effective, at least in the short run. ${ }^{16}$ This can create powerful incentives to use fiscal measures for political reasons (e.g. Clark \& Hallerberg, 2000; O'Mahony, 2011), which help explain why there were strong incentives for European governments not to adhere to the fiscal rules set forth in the Maastricht Treaty.

The trade-off between exchange-rate stability and domestic monetary policy autonomy becomes particularly acute in times of crisis, where governments operating under the constraint of fixed exchange rates have to implement painful domestic adjustments to address balance of

\footnotetext{
${ }^{16}$ In the long run, repeatedly substituting fiscal policy for monetary policy under fixed exchange rates can lead to the debt problems and crises now plaguing some of the peripheral countries within the Eurozone.
} 
payments imbalances. Much research has shown, however, that the resolution of such imbalances through "internal adjustment” is a politically contentious issue (Eichengreen, 1992; Leblang, 2003; Simmons, 1994; Walter, 2013). It typically involves high unemployment and falling asset prices in deficit countries and higher rates of inflation in surplus countries, and bars the option to let the exchange rate carry at least part of the necessary adjustment. It is quite obvious that, in both surplus and deficit countries, internal adjustment is not politically attractive.

Not surprisingly, the alternative to substantial internal adjustments in a currency union namely a financing of the current account deficits through public funds- has enjoyed broad support during the euro crisis. Bailout funds administered through the Troika or the TARGET2 balances within the ECB system have played an important role in European crisis management. However, this policy option also entails a number of trade-offs. For example, research on the politics of the International Monetary Fund (IMF) and its lending behavior has highlighted the trade-offs involved in granting and receiving bailouts in previous crises. This research has shown that answers to the question of who gets how much money under what conditions (and under what circumstances surplus countries are willing to pay) can vary significantly. Not all countries experiencing crisis are treated equally and political factors - notably, the interests of the Fund's large shareholders and the incentives of the IMF's professional bureaucrats - play an important role in this context (e.g. Copelovitch, 2010a, 2010b; Dreher et al., 2009; Dreher \& Vaubel, 2004; Thacker, 1999).

While much of this research assumes that such bailouts are limited, this may in fact not be true for the euro crisis. The increasing integration of financial markets has created new tradeoffs for the Eurozone (Obstfeld, 2013) and has put the question of fiscal and banking union and possibly a long-run transfer union on the table. This issue points to an additional complication: 
the potential contradiction between short-term and long-term policy goals. If the costs and benefits involved in the different choices were realized at the same time, many of the trade-offs invoked by the open economy trilemma and other economic constraints would be politically clearer. However, this is rarely the case. In terms of bailouts, this timing issue raises the possibility that the bailout facilities that were created to manage short-term pressures on national economies are transformed into a more permanent transfer union, which in turn raises the question as to whether member states would be willing to go along with this model. It also confronts European policymakers with an additional political trade-off between national autonomy and democratic accountability over fiscal policy, on the one hand, and financial and economic stability, on the other (Rodrik, 2011). In the long run, the fundamental problem facing European policymakers is likely to involve a choice between a closer union - involving more permanent transfers of funds among member states and the delegation of some fiscal autonomy to Brussels - or a break-up of the euro project in its current form.

In sum, the extensive literature on the political economy of money and finance highlights the difficult tradeoffs confronting policymakers as they wrestle with responses to the Euro crisis. At the same time, the politics of the Euro crisis are affected by the novel aspects of having a financial crisis occur within the economic and institutional context of a monetary union of advanced economies. It is therefore not surprising that the course of the euro crisis has been striking on many dimensions: the depth and long duration of the crisis, the extent of IMF involvement, the return of the specter of sovereign default in industrialized countries, the sudden stop in capital flows in developed countries, the prolonged deadlock among European governments and institutions about crisis resolution, and the threat that the crisis has posed to European integration itself. 
Apart from the inability of Eurozone countries to devalue their currencies, two key differences from previous debt and financial crises are particularly salient. First, prior to the euro crisis, nearly all modern experience with this international bargaining about crisis resolution involved developing countries and emerging markets, typically under the auspices of the International Monetary Fund. The international politics of the euro crisis has unfolded quite differently. While the IMF has been extensively involved as part of the Troika, most of the bargaining has taken place directly among member states of the European Union, along with the institutions of the EU more generally. In addition, with the notable exception of Greek debt and in marked contrast to previous financial crises - there has been little meaningful debt relief granted to the debtor nations. In other words, with the exception of Greece, most of the costs associated with the foreign debts accumulated between 1999 and 2008 have been borne by the debtors, while creditors have largely been rescued by a series of European and national packages to limit the impact of the debt crisis on national financial systems. Likewise, most of the cost of adjusting to the large current account balances has been borne by the deficit countries, which have seen large reductions in growth, jobs, and spending, whereas surplus countries have barely seen any increases in domestic consumption and inflation.

Second, perhaps the most salient distinguishing feature of the Euro crisis is that it has unfolded within the context of a long and ongoing historical process of regional economic integration, of which monetary union is now a central element. Both debtor and creditor nations within the Eurozone are also part of the broader single market of the European Union, within which goods, capital, and (most) people can move more or less as freely as they do within single nations. Nonetheless, while the single market was quite complete and there were many EU-wide political and regulatory institutions in place by 1999, substantial economic policy authority still 
remained vested in national states at the outset of the crisis. This includes, most importantly, fiscal policy and financial regulatory authority. Thus, the crisis has taken place - as no previous sovereign debt crisis had - within the unique economic and political context of an extensive yet incomplete regional integration scheme, where monetary and fiscal policy authority is divided between actors and institutions at both the supranational and national levels. While complicating the resolution of the crisis, these unique features make the euro crisis a useful and fascinating case for clarifying the scope conditions of existing theories in comparative and international economy.

\section{Contributions of the Special Issue}

As this short discussion illustrates, drawing on the large body of political economy research yields important insights for understanding the causes, consequences, and implications of financial crises in general and the Euro crisis in particular. Consequently, a key goal of this special issue project has been to bring together leading scholars in the field of international monetary and financial relations to draw on and extend this past work to provide a thorough treatment of the political economy of the euro crisis. While the substantive and methodological focus of the individual papers varies, the papers are bound by a common approach that emphasizes the primacy of domestic politics in shaping the key policy choices and outcomes we have observed at both the national and international levels during the euro crisis. The first three articles focus on analyzing the domestic distributive conflicts surrounding crisis management in deficit countries (Walter and Fernandez/Kuo) and surplus countries (Bernhard/Leblang). The article by Genovese, Schneider, and Wassmann shows how the ECB has been able to mitigate these conflicts to some extent. The paper by Baerg and Hallerberg then moves the focus of 
attention to interstate bargaining and the role of the European Commission. The special issue concludes with discussion by Jones, Kelemen, and Meunier about what the euro crisis implies for European integration. Overall, the papers highlight the centrality of domestic interests and institutions in shaping the choices confronting national and European policymakers in the wake of the euro crisis, as well as the central role of inter-state bargaining in shaping steps toward a resolution of the crisis.

The special issue starts out with the question of why austerity is easier to implement in some deficit countries than in others. Drawing on the experience of a related set of to balance-ofpayments crises in Eastern Europe, Stefanie Walter's paper demonstrates that the choice between the two main options of internal adjustment (i.e. austerity and structural reforms) and external adjustment (i.e. exchange-rate devaluation) depends on how costly each of these strategies is for a country. Four countries - Bulgaria, Estonia, Latvia, and Lithuania - chose the same strategy as the deficit countries in the Eurozone: internal adjustment rather than a devaluation of their currencies, an approach that plunged these countries into deep recessions but enjoyed wide popular support. In contrast, crisis resolution was much more difficult and contentious in Hungary and Romania where the costs of both internal and external adjustment were high, and largely uncontroversial in Poland and the Czech Republic, who devalued in response to the crisis. Walter shows that these differences in overall adjustment strategies and crisis politics were associated with variation in national "vulnerability profiles," but that each government designed the specific reforms in ways that best sheltered their own voters. These findings have important implications for understanding the domestic politics of the Euro crisis. All EMU crisis countries have embarked on a path of internal adjustment, but this path has been easier politically for some countries (e.g., Ireland and Cyprus) than others (e.g., Greece and Portugal). Walter's paper 
explains this variation and also highlights that the future costs of euro exit - while indiscriminately high - is likely to vary across EMU member states, based on domestic constituents’ vulnerability to external adjustment.

Focusing on one specific and important case of austerity in deficit countries, Jose Fernandez-Albertos and Alexander Kuo analyze domestic politics in Spain during the crisis. Their paper analyzes public opinion and firm survey data to understand what explains voter and firm preferences about continued euro membership and fiscal adjustment, that is over possible policies to address the Euro crisis. Among the public, they find far less euro skepticism than expected, along with much continued support for government spending on social programs, and these opinions are also related to individual crisis exposure. Critically, they also find among the general public that the individuals who oppose the euro and support more government spending (oppose austerity) are rather distinct groups of people, which could explain why the political articulation of a coherent alternative policy package to the status quo is particularly difficult in a country like Spain. Among firm managers and owners, they find much conservative support for staying in the Eurozone and for austerity, but such support is not correlated with firm-level economic suffering during the crisis. Thus, economic suffering divides citizens among policies they support, but not so among firms. Overall, these findings indicate that those who have suffered during the crisis are not necessarily the citizens demanding an end to austerity as it is currently practiced, and that among citizens who have not suffered as much, as well as firms, there is broad support for maintaining the euro. A key implication of these results is that changing status quo macroeconomic policies in Spain (and potentially in other debtor countries) will be difficult, because the main alternative policies (euro exit and ending austerity) have different types of supporters with conflicting interests. 
William Bernhard and David Leblang examine the domestic politics in Germany, the Eurozone's largest and most powerful surplus country. Focusing specifically on the second Greek bailout in 2011, they argue that the German government's decision to support the bailout represented a political choice: while a bailout would involve short-term political costs, Merkel's government also recognized the social and economic consequences of potential Greek default. In particular, a default entailed the prospect of a massive inflow of migrants from Southern Europe into Germany, which would have hurt labor markets and, in turn, could have cost Merkel's coalition electoral support. They employ models of credit default swap (CDS) spreads, studies of international migration, and research on vote intention to evaluate the political, economic, and social costs of the second Greek bailout within Germany. Their analysis has important implications for understanding both the Euro crisis and the links between capital mobility and migration within international political economy. Within the Eurozone, the analysis implies the threat of internal migration from the periphery made any sort of promise by surplus countries not to provide bailouts for Greece incredible. Thus, the free movement of people within the EU helped guarantee the credibility of the Euro and reduced bond rates for debt-ridden EU countries. More broadly, the analysis shows that political economy scholars cannot examine the implications of capital mobility and labor mobility in isolation. Potential migration pressure is an important factor in how governments in creditor countries respond to financial crises.

Federica Genovese, Gerald Schneider, and Pia Wassmann focus on the role of one key European institution, the European Central Bank, in alleviating political conflict in the crisisridden Eurozone countries. Their paper starts with the puzzle of the lack of large-scale protests in Eurozone member states against austerity measures during the crisis. Whereas political protests in Greece and Spain became more frequent and led to the formation of new parties with 
distinctive anti-austerity platforms, most crisis-ridden Eurozone members, including Italy and Ireland, experienced far less overt indignation in responses to the crisis and subsequent austerity measures than generally predicted. Using annual panel data and an original dataset of monthly political protests between 2001 and 2013, they argue that the interest rate adjustments and political announcements of the ECB limited the potential for mass unrest in Eurozone member states. The results suggest that the ECB was able to successfully assuage dissatisfaction with the limited reform options of the Eurozone member states in the wake of the crisis. Specifically, the authors identify the ECB actions, which culminated in July 2012, with President Draghi's famous statement to do "whatever it takes," as the mechanism that ultimately buffered the ongoing social crisis. The theoretical argument and empirical findings are consistent with classical models of social conflict in times of economic stress (e.g., Alesina \& Drazen, 1991), but stand in contrast to theories that see an undermining impact of EU integration on European welfare states (e.g., , 2011a; Streeck, 2011b).

Continuing with the focus on the European level, Nicole Baerg and Mark Hallerberg cast light on the international politics of the Euro crisis within European institutions. Drawing on an original dataset of European Commission assessments of member state economic programs and Council of Minister revisions, Baerg and Hallerberg show how politics within the Commission undermined the effectiveness of the Stability and Growth Pact over the last decade. Specifically, they find that powerful member-states - including Germany, France, and Italy - and governments with more euroskeptic populations behind them were most successful in weakening the Commission's warnings about Eurozone countries' fiscal performance since the Euro's inception. This weakening, they conclude, contributed to several large and/or euroskeptic member states entering the crisis with weaker public finances than had they followed the original 
Commission recommendations. At the same time, given that even small, euro-friendly states had the Commission's text weakened when the big and/or euroskeptic states were also receiving milder EU-level surveillance, debtor countries like Greece and Ireland also received weaker surveillance during the crisis, contributing to the build-up of unsustainable deficits. This political maneuvering within the Commission also had important indirect effects; notably, the larger and more euroskeptic states which entered the crisis with weaker finances were, quite likely, less able to agree to debt restructurings for the periphery countries because of the consequences for their own public finances.

In the final paper of the special issue, Erik Jones, Dan Kelemen, and Sophie Meunier step back to assess how the broader institutional context of European integration influenced both the onset of and response to the Euro crisis. They begin by noting that the EU project of combining a single market with a common currency was incomplete from its inception. As discussed above, this incompleteness of the governance architecture of EMU was both a cause of the euro crisis and a characteristic pattern of the policy responses to the crisis. In the paper, the authors develop a "failing forward" argument to explain the dynamics of European integration using recent experience in the eurozone as an illustration. They show how intergovernmental bargaining leads to incompleteness, because it forces states with diverse preferences to settle on lowest common denominator solutions. Incompleteness then unleashes forces that lead to crisis. Member states respond by again agreeing to lowest common denominator solutions, which address the crisis and lead to deeper integration. To date, this sequential cycle of piecemeal reform, followed by policy failure, followed by further reform, has managed to sustain both the European project and the common currency. However, the authors note that this approach entails clear risks for the future of both the Eurozone and the EU. Economically, the policy failures engendered by this 
incremental approach to the construction of EMU have been catastrophic for the citizens of many crisis-plagued member states. Politically, the perception that the EU is constantly in crisis and in need of reforms to salvage the union is undermining popular support for European integration. Thus, while "failing forward" may have advanced European integration to date, as a mode of institutional development it is self-undermining and may eventually prove unsustainable.

\section{Conclusion}

Ultimately, the papers in this special issue collectively highlight several key themes about the comparative and international political economy of the crisis. First, at the domestic level, the papers illustrate the increasingly important role of mass publics and public opinion in shaping policy responses to the euro crisis. While exchange-rate and monetary policy has long been thought to be a complex and technocratic field in which ordinary citizens have no well-informed interests (e.g. McNamara, 1998), this has changed in the setting of EMU and the euro crisis, where the consequences of these decisions have become much more visible and politicized. Most prominently, the Greek referendum on the proposed bailout package from July 2015 has turned the Greek people into a key actor in the crisis. But crisis politics have been politicized in surplus countries as well. For example, an unprecedented number of 37,000 German citizens called on the German constitutional court in 2012 to rule over whether the European Stability Mechanism was in line with the German constitution.

This demonstrates that it will become more difficult to make important decisions in crisis-related policy fields without consideration of the public's reactions. Mass publics are also increasingly important because of the broad macroeconomic consequences of EMU. For example, high unemployment rates in peripheral countries and increasing shares of non-performing loans 
on bank balance sheets leave households directly exposed to the effects of the crisis. In addition, the growing importance of mass public opinion is visible in the growing concern among ordinary citizens about the future direction of the European project more generally (Cramme \& Hobolt, 2014; Frieden, 2016; Hooghe \& Marks, 2009) and the increasing success of euroskeptic parties across Europe (Usherwood \& Startin, 2013).

Second, the papers in this special issue highlight the increasing reach of the crisis into the domestic politics of Eurozone member-states. As is now abundantly clear, the currency union not only affects monetary and exchange rate policy (and fiscal policy), but also the relationship between monetary policy and such other arenas as labor market policies and financial regulation. EMU has had far more intrusive and far-reaching consequences on national economies than many Europeans realized at the time of its founding. This has been evident in the conditions imposed on debtor countries by the Troika, which span a large variety of policies, but which also have varied substantially across cases and over time during the euro crisis. Moreover, the domestic reach of the crisis extends to all member states, as European-level decisions - such as bailout programs, banking union, or banking supervision - have important effects at the national level. As a result, negotiations about such decisions within supranational institutions such as the European Commission and the Troika have been very difficult and contentious, and have been strongly influenced by the national interests affected by these decisions.

Third, as we have noted earlier, the special issue shows how the underlying economic problems of the Eurozone have persisted since its inception and continue to have enormous economic and political implications today. Increasingly, then, the appropriate analogy for the Eurozone is not the Great Depression, but rather Japan, which has been mired in an era of stagnation since the 1990s, and whose persistent problems (debt-laden banks, unfavorable 
demographics, persistent deflationary pressures) appear disturbingly similar to those of the Eurozone today. Faced with the possibility of long-term "secular stagnation" (Summers, 2014), Europe's debt problems look even more serious and threatening to the long-term success of EMU. Unless economic growth returns to the Euro area, Greece and other member-states face the possibility of decades of grinding deflation, long-term unemployment, and stagnation. Given the persistent and massive unemployment in the debtor countries, as well as the major electoral shakeups seen to date within Eurozone member-states, this scenario does not bode well for the future of European monetary integration. Indeed, as Jones, Kelemen, and Meunier conclude in their own paper, "failing forward" through incomplete (but politically expedient) policy responses that mitigate but do not resolve the Eurozone crisis may have worked thus far, but it is not a recipe for the long-term success and sustainability of either the Eurozone or the broader European Union.

Ultimately, the key debates about the structure of Eurozone governance have changed little since the 1990s. In the years between the signing of the Maastricht Treaty and the launch of the Euro, it became very clear that, while policymakers were unified in their goal of creating a stable Euro and Eurozone, domestic politics within EMU member-states were such that no country was able to agree to the sorts of policies and institutions that would have enabled the Eurozone to avoid the problems that have plagued it since 2010. In this sense, there is a plus ça change quality about the political and economic debates within the Eurozone today. Faced with the same set of persistent macroeconomic imbalances and similar implacable domestic political barriers to further integration, European policymakers and national-level politicians in EMU member-states continue to face serious questions about the future stability and prospects of the single currency, and these are further tested as the EU faces additional challenges in other policy 
fields such as the refugee crisis or the conflict between Russia and Ukraine. Ensuring the longterm viability of the monetary union will require policymakers to adopt some combination of the policies and institutions- a true Eurozone lender of last resort, a growth and stability pact with strict monitoring and enforcement mechanisms, increased labor mobility between Eurozone member-states, and/or a more extensive fiscal and political union - necessary to maintain a monetary union among disparate national economies with large and persistent macroeconomic imbalances.

Whether or not European policymakers are able to overcome the domestic and international obstacles to such cooperation is, as always, a political rather than an economic question. Indeed, it is important to note that there are no technical obstacles to the adoption of any of the policy or institutional solutions to resolving the Euro crisis and addressing the imbalances within the monetary union. The ultimate problem is that adoption of any of them remains, now and for the foreseeable future, politically infeasible. Through this special issue, we have attempted to provide a set of tools and analyses that shed light on the politics of the Euro crisis - grounded in the robust existing literature on the political economy of international money and finance - and which will be equally useful for scholars of comparative politics, European integration, and the political economy of international money and finance. Our hope is that the papers included here serve as the starting point of a deeper and more extensive conversation and collaboration between these groups of scholars that will lead to a richer and clearer understanding of the nature of politics within the European monetary union in the years ahead. 


\section{References}

Alesina, A., \& Drazen, A. (1991). Why are Stabilizations Delayed? American Economic Review, 81, 1170-1188.

Baldwin, R., Beck, T., Bénassy-Quéré, A., Blanchard, O., Corsetti, G., de Grauwe, P., et al. (2015). Rebooting the Eurozone: Step 1 - agreeing a crisis narrative. CEPR POLICY INSIGHT 85, 1-15.

Bayoumi, T., \& Eichengreen, B. (1992). Shocking aspects of European monetary unification. NBER Working Paper No. 3949.

Bearce, D. H. (2003). Societal Preferences, Partisan Agents, and Monetary Policy Outcomes. International Organization, 57, 373-410.

Bearce, D. H., \& Hallerberg, M. (2011). Democracy and De Facto Exchange Rate Regimes. Economics \& Politics, 23(2), 172-194.

Bechtel, M. M., Hainmueller, J., \& Margalit, Y. (2014). Preferences for International Redistribution: The Divide over the Eurozone Bailouts. American Journal of Political Science.

Bellucci, P., Lobo, M. C., \& Lewis-Beck, M. S. (2012). Economic crisis and elections: The European periphery. Electoral Studies, 31(3), 469-471.

Bernhard, W., Broz, J. L., \& Clark, W. R. (2002). The Political Economy of Monetary Institutions. International Organization, 56(4), 693-723.

Bernhard, W., \& Leblang, D. (1999). Democratic Institutions and Exchange-rate Commitments. International Organization, 53(1), 71-97.

Bernoth, K., \& Erdogan, B. (2012). Sovereign bond yield spreads: A time-varying coefficient approach. Journal of International Money and Finance, 31(3), 639-656.

Bernoth, K., Von Hagen, J., \& Schuknecht, L. (2012). Sovereign risk premiums in the European government bond market. Journal of International Money and Finance, 31(5), 975-995.

Bodea, C. (2010). The political economy of fixed exchange rate regimes: The experience of postcommunist countries. European Journal of Political Economy, 26(2), 248-264.

Broz, J. L. (2002). Political System Transparency and Monetary Commitment Regimes. International Organization, 56(4), 861-887.

Calvo, G. A. (1998). Capital Flows and Capital-Market Crises. The Simple Economics of Sudden Stops. Journal of Applied Economics, 1(1), 35-54.

Carlin, W., \& Soskice, D. (2014). Macroeconomics: Institutions, Instability, and the Financial System: Oxford University Press.

Chang, M., \& Leblond, P. (2014). All in: Market expectations of eurozone integrity in the sovereign debt crisis. Review of International Political Economy(ahead-of-print), 1-30.

Chinn, M., \& Frieden, J. (2011). Lost Decades. The Making of America's Debt Crisis and the Long Recovery. New York: W.W. Norton.

Chwieroth, J. M. (2009). Capital ideas: The IMF and the rise of financial liberalization: Princeton University Press.

Clark, W. R., \& Hallerberg, M. (2000). Mobile Capital, Domestic Institutions, and Electorally Induced Monetary and Fiscal Policy. American Political Science Review, 94(2), 323-346.

Cohen, B. (2008). Introduction to International Political Economy: An Intellectual History. Princeton: Princeton University Press. 
Copelovitch, M. (2010a). The International Monetary Fund in the Global Economy. Cambridge: Cambridge University Press.

Copelovitch, M. (2010b). Master or Servant? Common Agency and the Political Economy of IMF Lending. International Studies Quarterly, 54(1), 49-77.

Copelovitch, M., \& Singer, D. (2008). Financial Regulation, Monetary Policy, and Inflation in the Industrialized World. Journal of Politics, 70(3), 663-680.

Crafts, N. (2013). The Eurozone: If Only It Were the 1930s, VOX. CEPR's Policy Portal. http://www.voxeu.org: CEPR.

Cramme, O., \& Hobolt, S. B. (2014). Democratic Politics in a European Union Under Stress. Oxford: Oxford University Press.

De Grauwe, P. (2013). Design Failures in the Eurozone: Can they be fixed? LSE 'Europe in Question' Discussion Paper Series, 57(February).

Dinas, E., Jurado, I., Konstantinidis, N., \& Walter, S. (2015). Survey evidence from the July 2015 Greek referendum and the September 2015 Greek elections.

Dreher, A., Sturm, J.-E., \& Vreeland, J. (2009). Global horse trading: IMF loans for votes in the United Nations Security Council. European Economic Review, 53(7), 742-757.

Dreher, A., \& Vaubel, R. (2004). The causes and consequences of IMF conditionality. Emerging Markets Finance and Trade, 40(3), 26-54.

Dyson, K., \& Featherstone, K. (1999). The road to Maastricht: negotiating economic and monetary union. Oxford: Oxford University Press.

Eichengreen, B. (1992). Golden Fetters: The Gold Standard and the Great Depression. New York: Oxford University Press.

Eichengreen, B., \& Frieden, J. (2001). The Political Economy of European Monetary Unification: Westview Press.

Enderlein, H., \& Verdun, A. (2009). EMU's teenage challenge: what have we learned and can we predict from political science? Journal of European Public Policy, 16(4), 490-507.

Eurobarometer. (2012). Public Opinion in the European Union. First results from Eurobarometer 78 (November 2012 ed. Vol. 78). Brussels: European Commission.

Frieden, J. (1991a). Debt, Development, and Democracy. Princeton: Princeton University Press.

Frieden, J. (1991b). Invested Interests: The Politics of National Economic policies in a World of Global Finance. International Organization, 45(4), 425-451.

Frieden, J. (2002). Real Sources of European Currency Policy: Sectoral Interests and European Monetary Integration. International Organization, 56(4), 831-860.

Frieden, J. (2015). The political economy of adjustment and rebalancing. Journal of International Money and Finance, 52, 4-14.

Frieden, J. (2016). The crisis, the public, and the futureof European integration. In F. Caselli, M. Centeno \& J. A. Tavares (Eds.), After the Crisis: Reform, Recovery, and Growth in Europe. Oxford: Oxford University Press.

Ghosh, A. R., Ostry, J. D., \& Qureshi, M. S. (2013). Fiscal space and sovereign risk pricing in a currency union. Journal of International Money and finance, 34, 131-163.

Gocaj, L., \& Meunier, S. (2013). Time Will Tell: The EFSF, the ESM, and the Euro Crisis. Journal of European Integration, 35(3).

Gray, J. (2013). The Company States Keep. International Economic Organizations and Investor Perceptions. Cambridge: Cambridge University Press.

Haggard, S., \& Maxfield, S. (1996). The political economy of financial internationalization in the developing world. International Organization, 50(01), 35-68. 
Hall, M. (2008). Democracy and Floating Exchange Rates. International Political Science Review, 29(1), 73-98.

Hall, P. (2012). The Economics and Politics of the Euro Crisis. German Politics, 21(4), 355-371.

Hall, P. A., \& Franzese, R. J. (1998). Mixed signals: central bank independence, coordinated wage bargaining, and European Monetary Union. International organization, 52(03), 505-535.

Hallerberg, M. (2002). Veto Players and the Choice of Monetary Institutions. International Organization, 56(4), 775-802.

Heins, E., \& de la Porte, C. (2015). The sovereign debt crisis, the EU and welfare state reform. Comparative European Politics, 13(1), 1-7.

Hooghe, L., \& Marks, G. (2009). A Postfunctionalist Theory of European Integration: From Permissive Consensus to Constraining Dissenus. British Journal of Political Science, 39(1), 1-23.

Ioannou, D., Leblond, P., \& Niemann, A. (2015). European integration and the crisis: practice and theory. Journal of European Public Policy, 22(2), 155-176.

Johnston, A., Hancké, B., \& Pant, S. (2014). Comparative institutional advantage in the European sovereign debt crisis. Comparative Political Studies, 47(13), 1771-1800.

Jonung, L., \& Drea, E. (2010). It can't happen, it's a bad idea, it won't last: US economists on the EMU and the Euro, 1989-2002. Econ Journal Watch, 7(1), 4-52.

Keefer, P., \& Stasavage, D. (2002). Checks and Balances, Private Information, and the Credibility of Monetary Commitments. International Organization, 56(4), 751-774.

Kenen, P. B. (1969). The Theory of Optimum Currency Areas: An Eclectic View. In R. Mundell \& A. Swoboda (Eds.), Monetary Problems of the International Economy. Chicago: University of Chicago Press.

Lane, P. R. (2012). The European sovereign debt crisis. The Journal of Economic Perspectives, 26(3), 49-67.

Leblang, D. (1999). Domestic Political Institutions and Exchange Rate Commitments in the Developing World. International Studies Quarterly, 43(4), 599-620.

Leblang, D. (2003). To Devalue or to Defend? The Political Economy of Exchange Rate Policy. International Studies Quarterly, 47(4), 533-559.

McKinnon, R. I. (1963). Optimum Currency Areas. The American Economic Review, 53(4), 717725.

McNamara, K. (1998). The Currency of Ideas: Monetary Politics in the European Union. Ithaca: Cornell University Press.

Menz, G., \& Smith, M. (2013). Special Issue: Redefining European Economic Governance. Journal of European Integration, 35(3), 195-373.

Mody, A., \& Sandri, D. (2012). The eurozone crisis: how banks and sovereigns came to be joined at the hip. Economic Policy, 27(70), 199-230.

Mosley, L. (2003). Global Capital and National Governments. New York: Cambridge University Press.

Mundell, R. (1961). A theory of optimum currency areas. American Economic Review, 51(4), 657-664.

Mundell, R. (1963). Capital Mobility and Stabilization Policy under Fixed and Flexible Exchange Rates. Canadian Journal of Economics and Political Science, 29(November), 475-485. 
O'Mahony, A. (2011). Engineering Good Times: Fiscal Manipulation in a Global Economy. British Journal of Political Science, 41(2), 315-340.

Obstfeld, M. (2013). Finance at Center Stage: Some Lessons of the Euro Crisis.Unpublished manuscript.

Pepinsky, T. B. (2009). Economic Crises and the Breakdown of Authoritarian Regimes: Indonesia and Malaysia in Comparative Perspective (1 ed.). Cambridge: Cambridge University Press.

Pisani-Ferry, J. (2012). The euro crisis and the new impossible trinity: Bruegel Policy Contribution.

Quinn, D. P., \& Toyoda, A. M. (2007). Ideology and voter preferences as determinants of financial globalization. American Journal of Political Science, 51(2), 344-363.

Reinhart, C., \& Rogoff, K. (2010). This Time is Different: Eight Centuries of Financial Folly. Princeton: Princeton University Press.

Rickard, S. J., \& Caraway, T. L. (2014). International Negotiations in the Shadow of National Elections. International Organization, 68(03), 701-720.

Rodrik, D. (2011). The globalization paradox: democracy and the future of the world economy. New York: W. W. Norton \& Company.

Sandholtz, W. (1993). Choosing Union: Monetary Politics and Maastricht. International Organization, 47(1), 1-39.

Sattler, T., \& Walter, S. (2010). Monetary Credibility vs. Voter Approval: Political Institutions and Exchange-Rate Stabilization during Crises. Economics and Politics, 22(3), 392-418.

Satyanath, S. (2006). Globalization, Politics, and Financial Turmoil: Asia's Banking Crisis. Cambridge: Cambrige University Press.

Scharpf, F. (2013). Monetary Union, Fiscal Crisis and the Disabling of Democratic Accountability. In A. Schäfer \& W. Streeck (Eds.), Politics in the Age of Austerity: Polity Press.

Simmons, B. (1994). Who Adjusts? Domestic Sources of Foreign Economic Policy During the Interwar Years. Princeton, NJ: Princeton University Press.

Simmons, B., \& Elkins, Z. (2004). The globalization of liberalization: Policy diffusion in the international political economy. American political science review, 98(01), 171-189.

Singer, D. (2004). Capital Rules: The Domestic Politics of International Regulatory Harmonization. International Organization, 58(3), 531-565.

Steinberg, D. (2015). Demanding Devaluation: Exchange Rate Politics in the Developing World: Cornell University Press.

Streeck, W. (2011a). The crisis in context: Democratic capitalism and its contradictions. MaxPlanck-Institut für Gesellschaftsforschung Discussion Paper(11/15).

Streeck, W. (2011b). Taking capitalism seriously: towards an institutionalist approach to contemporary political economy. Socio-Economic Review, 9(1), 137-167.

Summers, L. H. (2014). US economic prospects: Secular stagnation, hysteresis, and the zero lower bound. Business Economics, 49(2), 65-73.

Thacker, S. (1999). The high politics of IMF lending. World Politics, 52(1), 38-75.

Tosun, J., Wetzel, A., \& Zapryanova, G. (2014). The EU in crisis: advancing the debate. Journal of European Integration, 36(3), 195-211.

Usherwood, S., \& Startin, N. (2013). Euroscepticism as a Persistent Phenomenon*. JCMS: Journal of Common Market Studies, 51(1), 1-16. 
Vreeland, J. R. (2003). The IMF and Economic Development. Cambridge: Cambridge University Press.

Walter, S. (2008). A New Approach for Determining Exchange-Rate Level Preferences. International Organization, 62(3), 405-438.

Walter, S. (2013). Financial Crises and the Politics of Macroeconomic Adjustment. Cambridge: Cambridge University Press.

Wihlborg, C., Willett, T., \& Zhang, N. (2010). The Euro Debt Crisis. It isn't just fiscal. World Economics, 11(4).

World Bank. (2014). World Development Indicators. Washington DC: World Bank. 